\title{
Ultraviolet radiation sensitivity and reduction of telomeric silencing in Saccharomyces cerevisiae cells lacking chromatin assembly factor-I
}

\author{
Paul D. Kaufman, ${ }^{1-4}$ Ryuji Kobayashi, ${ }^{1}$ and Bruce Stillman ${ }^{1}$ \\ ${ }^{1}$ Cold Spring Harbor Laboratory, Cold Spring Harbor, New York 11724 USA; ${ }^{2}$ Lawrence Berkeley National Laboratory, \\ Berkeley, California 94720 USA; ${ }^{3}$ University of California, Berkeley, Department of Molecular and Cell Biology, \\ Berkeley, California 94720-3206 USA
}

In vivo, nucleosomes are formed rapidly on newly synthesized DNA after polymerase passage. Previously, a protein complex from human cells, termed chromatin assembly factor-I (CAF-I), was isolated that assembles nucleosomes preferentially onto SV40 DNA templates that undergo replication in vitro. Using a similar assay, we now report the purification of CAF-I from the budding yeast Saccharomyces cerevisiae. Amino acid sequence data from purified yeast CAF-I led to identification of the genes encoding each subunit in the yeast genome data base. The $C A C 1$ and $C A C 2$ (chromatin assembly complex) genes encode proteins similar to the p150 and p60 subunits of human CAF-I, respectively. The gene encoding the p50 subunit of yeast CAF-I (CAC3) is similar to the human p48 CAF-I subunit and was identified previously as MSI1, a member of a highly conserved subfamily of WD repeat proteins implicated in histone function in several organisms. Thus, CAF-I has been conserved functionally and structurally from yeast to human cells. Genes encoding the CAF-I subunits (collectively referred to as CAC genes) are not essential for cell viability. However, deletion of any $C A C$ gene causes an increase in sensitivity to ultraviolet radiation, without significantly increasing sensitivity to gamma rays. This is consistent with previous biochemical data demonstrating the ability of CAF-I to assemble nucleosomes on templates undergoing nucleotide excision repair. Deletion of $C A C$ genes also strongly reduces silencing of genes adjacent to telomeric DNA; the CAC1 gene is identical to RLF2 (Rap1p localization factor-2), a gene required for the normal distribution of the telomere-binding Rap1p protein within the nucleus. Together, these data suggest that CAF-I plays a role in generating chromatin structures in vivo.

[Key Words: Nucleosome; DNA damage; heterochromatin; DNA replication]

Received October 8, 1996; revised version accepted December 4, 1996.

The first chromatin proteins deposited onto nascent DNA are the core histones, resulting in formation of nucleosomes (Worcel et al. 1978). Nucleosomes are the fundamental repeat structures of chromatin and are comprised of $146 \mathrm{bp}$ of DNA wrapped around an octamer of histone proteins / two molecules of each of the core histones $\mathrm{H} 2 \mathrm{~A}, \mathrm{H} 2 \mathrm{~B}, \mathrm{H} 3$, and $\mathrm{H} 4$; for review, see van Holde 1989). In the budding yeast Saccharomyces cerevisiae, DNA replication in the absence of expression of one of the core histones results in a loss of viability that cannot be rescued by later expression of the missing histone (Han et al. 1987; Kim et al. 1988). Therefore, proper coordination between DNA replication and nucleosome assembly is an essential process.

${ }^{4}$ Corresponding author. Present addresses: Lawrence Berkeley National Laboratory and Department of Molecular and Cell Biology, University of California, Berkeley, California 94720-3206 USA.

E-MAIL pkauf@mendel.berkeley.edu; FAX (510) 486-6488.
During DNA replication, existing nucleosomes on the parental DNA are segregated randomly onto the two nascent DNA duplexes (Sogo et al. 1986; for review, see Kaufman and Botchan 1994; Krude 1995b). During each round of DNA replication, half of the nucleosomes are formed from newly synthesized histones in two steps. Newly synthesized histones $\mathrm{H} 3$ and $\mathrm{H} 4$ are deposited onto DNA first, followed by histones $\mathrm{H} 2 \mathrm{~A} / \mathrm{H} 2 \mathrm{~B}$, to complete the nucleosome (Worcel et al. 1978; Jackson 1990; Smith and Stillman 1991). Existing nucleosomes on the parental DNA template are segregated to nascent DNA efficiently in vitro in highly purified DNA replication systems (Ishimi et al. 1991). In contrast, additional cellular factors are required for deposition of newly synthesized histones during DNA replication (for review, see Kaufman and Botchan 1994; Krude 1995b).

It is presently unknown which proteins mediate assembly of histones onto DNA in vivo. Biochemical ap- 
proaches to this problem have often used extracts of egg or embryonic cells from Xenopus and Drosophila (Laskey et al. 1977; Glikin et al. 1984; Becker and Wu 1992; Kamakaka et al. 1993). Such extracts assemble nucleosomes efficiently because embryos typically contain a large maternal store of histones bound to acidic "chaperone" proteins. Several of the proteins from Xenopus that mediate nucleosome assembly in vitro have been purified and cloned (Kleinschmidt et al. 1986; Dingwall et al. 1987); however, these factors do not require DNA synthesis to assemble nucleosomes. Therefore, these factors operate by mechanisms that do not reflect adequately the observed link between replication fork passage and assembly of nucleosomes in mammalian somatic cells. Also, in contrast to embryonic cells, somatic cells generally do not store large pools of histones. Instead, most histones are synthesized in a cell cycle-dependent manner at the onset on DNA synthesis, just before de novo nucleosome assembly occurs $(\mathrm{Wu}$ and Bonner 1981; Russev and Hancock 1982; Jackson 1990). Therefore, an understanding of how chromatin assembly is regulated in somatic cells requires functional characterization of proteins that link assembly of nucleosomes to DNA replication.

A three-subunit protein complex termed chromatin assembly factor-I (CAF-I) was purified from human somatic cell nuclear extracts based on its ability to assemble histone octamers onto SV40 origin-based plasmids undergoing replication in vitro (Stillman 1986; Smith and Stillman 1989; for review, see Krude 1995b; Kaufman 1996). CAF-I differs from other assembly factors because it assembles nucleosomes preferentially on DNA that has recently undergone DNA replication (Smith and Stillman 1989; Kaufman et al. 1995; Kamakaka et al. 1996). CAF-I performs the first step of the assembly process, bringing histones $\mathrm{H} 3$ and $\mathrm{H} 4$ to replicating DNA; histones $\mathrm{H} 2 \mathrm{~A} / \mathrm{H} 2 \mathrm{~B}$ can bind to this "chromatin precursor" subsequent to DNA replication to complete the histone octamer (Smith and Stillman 1991). Thus, CAF-I assembles nucleosomes in vitro by the same two-step mechanism observed in vivo, and it does so in a manner linked to DNA replication. The nature of the molecular signal that governs DNA replication-preferential activity of CAF-I is not known presently. CAF-I forms nucleosomes for a short period after inhibition of DNA synthesis (Kamakaka et al. 1996), and can perform nucleosome assembly on DNA templates undergoing nucleotide excision repair (Gaillard et al. 1996). These data are consistent with a model in which CAF-I is activated by proteins or nucleic acid structures, or both, left in the wake of DNA polymerases (Kaufman 1996). In S-phase nuclei of human cells, CAF-I colocalizes with punctate DNA replication foci (Krude 1995a), suggesting that CAF-I plays a role in the new nucleosome assembly at least at some of the clustered DNA replication forks at each focus.

Human CAF-I is comprised of subunits termed p150, p60, and p48 (Smith and Stillman 1989; Verreault et al. 1996). p150 is an acidic protein with several highly charged regions; the other subunits, p60 and p48, contain
WD repeats (Kaufman et al. 1995; Verreault et al. 1996), a prevalent repeating motif in many eukaryotic proteins (Neer et al. 1994). The p48 subunit is a member of a highly conserved subfamily of WD proteins. This subfamily has been implicated in multiple aspects of histone metabolism (Parthun et al. 1996; Taunton et al. 1996; Verreault et al. 1996). In this paper we have purified a DNA replication-linked chromatin assembly factor from $S$. cerevisiae to study formation of chromosomes by both biochemical and genetic techniques. This approach led to the identification of a yeast CAF-I protein complex that is molecularly and structurally similar to that purified from human cells.

\section{Results}

Detection and purification of a yeast DNA replication-linked chromatin assembly factor

Although candidate homologs of the human CAF-I subunits were present in yeast genome data base entries, the presence of multiple p48-related proteins in yeast made it impossible to identify genes involved in nucleosome assembly unambiguously. Therefore, we searched for biochemical activities from yeast cell extracts that assemble nucleosomes in a DNA replication-preferential manner during SV40 DNA replication in vitro. In this assay, DNA templates that undergo replication are labeled by incorporation of radioactive dATP. After DNA synthesis, proteins are removed from the DNA templates by phenol extraction, and the purified DNA is analyzed by agarose gel electrophoresis. Formation of nucleosomes during the synthesis stage is detected by an increase in the negative supercoiling of the purified DNA (see Stillman 1986 and references therein).

Previously, our biochemical interspecies complementation approach has allowed detection of CAF-I like-activities from Drosophila and Xenopus embryo extracts (Gaillard et al. 1996; Kamakaka et al. 1994, 1996). On the basis of the successful purification of other yeast proteins, whole cell extracts were prepared by glass beadbeating of late log-phase cells (Bell et al. 1993). Initial experiments showed that material from the initial cation exchange column that eluted at a conductivity equivalent to the starting buffer plus $0.27 \mathrm{M} \mathrm{NaCl}$ contained a replication-preferential nucleosome assembly activity that would be revealed after subsequent anion exchange chromatography (see Materials and Methods). This activity could not be detected reliably earlier in the purification because of replication-independent DNA supercoiling activities in chromatographic fractions from the first column, including the ABFII protein (data not shown; see Diffley and Stillman 1991).

As shown previously for human CAF-I (Smith and Stillman 19891, the yeast nucleosome assembly factor binds to columns of histone-agarose (Fig. 1A), although it is eluted at lower salt concentrations than human CAF-I. These chromatographic fractions were assayed. Comparison of the autoradiograph of synthetically labeled replication products with total DNA detected by ethid- 


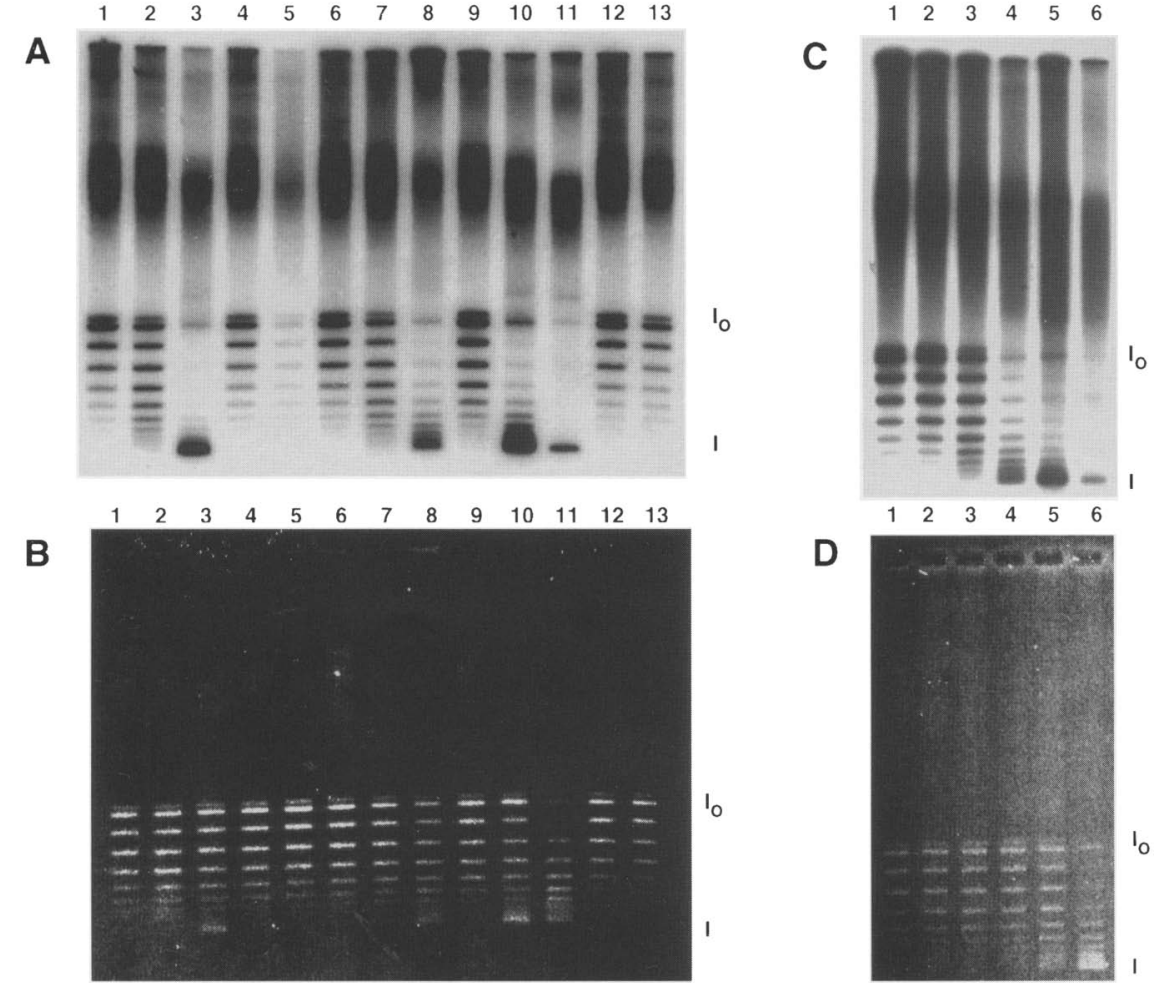

Figure 1. Identification of a histone-binding, DNA replication-preferential nucleosome assembly factor in yeast extracts. $(A)$ Nucleosome assembly assay of histone-agarose chromatography fractions. A singlestranded DNA (ssDNA) cellulose column fraction was loaded onto a histone-agarose column and bound proteins were eluted with increasing $\mathrm{NaCl}$ as described in $\mathrm{Ma}$ terials and Methods. SV40 DNA replication reactions were performed with the addition of no additional protein (lane 1), input ssDNA fraction $(0.5$ and $2 \mu l$; lanes 2,3), histone-agarose column flowthrough ( 1 and $4 \mu \mathrm{l}$; lanes 4,5), histone-agarose 0.2 $\mathrm{MNaCl}$ elution $(0.04,0.2$, and $0.5 \mu \mathrm{l}$; lanes 6-8), histone-agarose $0.4 \mathrm{M} \mathrm{NaCl}$ elution $(0.04,0.2$, and $0.5 \mu \mathrm{l}$; lanes 9-11), and histone-agarose $0.6 \mathrm{M} \mathrm{NaCl}$ elution 10.2 and $0.5 \mu \mathrm{l}$; lanes 12,13). $\left(\mathrm{I}_{\mathrm{o}}\right)$ The migration of topologically relaxed circular DNA templates; (I) The migration of supercoiled DNA indicative of nucleosome assembly. (B) Ethidium bromide stain of the gel shown in $A$. Even when sufficient CAF-I had been added to convert the majority of replicated DNA into a highly supercoiled species $(A$, lanes $3,8,10,11)$, not all of the unreplicated DNA molecules detected by ethidium staining are supercoiled. This indicates preferential assembly of nucleosomes on the replicated DNA templates. (C) Titration of purified yeast CAF-I. Glycerol gradient-purified yeast CAF-I (fraction 5 from the gradient shown in Fig. 2) was titrated in the nucleosome assembly assay. The equivalents of $0,0.15,0.3,0.6,1.2$, and $2.4 \mu \mathrm{l}$ of fraction 5 were added to 25 - $\mu$ l replication reactions in lanes 1 through 6 , respectively. (D) Ethidium bromide stain of the gel shown in $C$.

ium bromide staining (Fig. 1B) shows that replicated DNA was assembled preferentially into chromatin, as revealed by the formation of negatively supercoiled DNA (form I in Fig. 1 and 2). Human CAF-I displays a similar preference (Smith and Stillman 1989; Kaufman et al. 1995). The yeast assembly factor was purified extensively on a preparative scale by four chromatographic steps and glycerol gradient sedimentation (see Materials and Methods). When added at oversaturated amounts, a highly purified yeast assembly factor inhibits DNA synthesis and causes bulk supercoiling of input DNA (Fig. $1 C, D$, lane 6). This property is shared by the human and Drosophila CAF-I proteins (Kamakaka et al. 1996). However, at subsaturating amounts of yeast CAF-I (Fig. 1C,D, lanes 4,5), replicated molecules are supercoiled preferentially compared to the total input DNA.

To demonstrate that the supercoiling of DNA molecules by yeast assembly factor reflects assembly of nucleosomes, DNA replication products were analyzed by micrococcal nuclease (MNase) digestion. Limited digestion with MNase results in preferential cleavage of the linker DNA between nucleosomes; nucleosome assembly by human and Drosophila CAF-I results in protection of a ladder of DNA bands from MNase digestion (Smith and Stillman 1989; Kaufman et al. 1995; Kamakaka et al. 1996). We show here that recombinant human CAF-I and glycerol gradient-purified yeast assem- bly factor generate replication products that display an identical pattern of MNase-resistant DNA (Fig. 2D). Therefore, we refer to the purified protein complex as yeast CAF-I.

Glycerol-gradient purified yeast CAF-I from several preparations consistently contained three polypeptides (p90, p60, and p50) that cosedimented in the glycerol gradient (Fig. 2A-C). Other proteins in similar gradientpurified preparations did not always peak in the same fraction as CAF-I activity (data not shown). As noted above, the high concentration of CAF-I in the peak fractions inhibited DNA replication (Fig. 2B, lanes 5-7). Sufficient amounts of each of the three candidate proteins were purified for amino acid sequence determination. Screening of the yeast genome data base with the peptide sequence data resulted in identification of the genes encoding each of the yeast CAF-I subunits. Each of these yeast genes is similar to the respective human CAF-I subunit gene (Fig. 3; also see Verreault et al. 1996). The genes encoding the $\mathrm{p} 90, \mathrm{p} 60$, and $\mathrm{p} 50$ subunits of yeast CAF-I were called CAC1, CAC2, and CAC3, respectively, because they were isolated as members of a chromatin assembly complex (the acronym $C A F$ had been used previously for unrelated yeast genes). CAC3 had been isolated previously and termed MSI1 (see below). All the peptides sequenced were found in these three genes. 

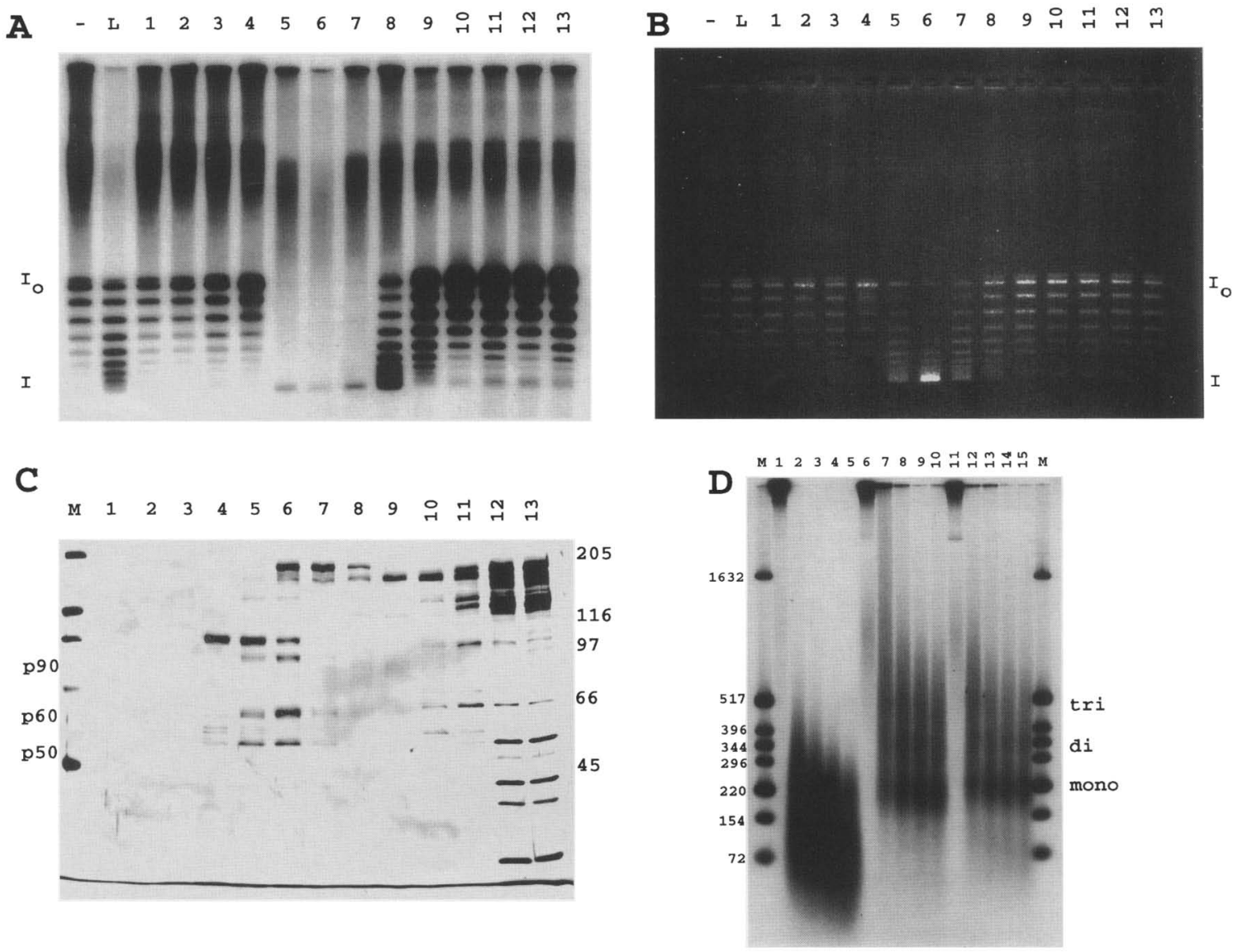

Figure 2. Preparative purification of yeast CAF-I. (A) Nucleosome assembly assay of glycerol gradient purified yeast CAF-I. SV40 DNA replication reactions were performed with the addition of glycerol gradient-purified yeast CAF-I (numbered lanes, corresponding to numbered protein fractions shown in $C$ ), material loaded onto the gradient (lane $\mathrm{L}$ ), or no additional protein (lane - ). DNA products were analyzed by agarose gel electrophoresis; an autoradiograph of synthetically labeled DNA is shown. Migration of topologically relaxed DNA $\left(\mathrm{I}_{\mathrm{o}}\right)$ and negatively supercoiled DNA $(\mathrm{I})$ is indicated; the material migrating slightly more slowly than the form I band in lanes 10-13 is unwound, and not supercoiled molecules. (B) Ethidium bromide stain of the gel shown in $A$. Note that when CAF-I was present but not oversaturated (e.g., lanes L, 5,7), labeled monomeric DNA was supercoiled but not all of the DNA in the reaction was. This indicates preferential assembly of nucleosomes on the replicated DNA templates. $(C)$ Proteins were analyzed by SDS-PAGE and stained with silver. Numbered lanes indicate gradient fractions, increasing from top to bottom. Lane M shows marker proteins $(205$, $116,97,66$, and $45 \mathrm{kD}$ from top to bottom, migration indicated to the right). The migration of the CAF-I p90, p60, and p50 subunits (peaking in fraction 6) is shown to the left. This preparation of protein was used for amino acid sequence analysis. $(D)$ MNase digestion of replication products. SV40 DNA replication reactions (120 $\mu$ l) were supplemented with histones $\mathrm{H} 2 \mathrm{~A}$ and $\mathrm{H} 2 \mathrm{~B}$ (see Materials and Methods) and no assembly factor (lanes 1-5), recombinant human CAF-I p150 (60 ng; lanes 6-10) or $7 \mu$ of glycerol gradient-purified yeast CAF-I (fraction 5 above; lanes 11-15). Reaction products were digested with MNase for 0 min (lanes 1,6,11), 10 min (lanes 2,7,12), $20 \mathrm{~min}$ (lanes $3,8,13$ ), $30 \mathrm{~min}$ (lanes 4,9,14), or $40 \mathrm{~min}$ (lanes 5,10,15) before deproteinization and electrophoresis through a $2 \%$ agarose gel. Molecular mass markers (M) with sizes in base pairs are indicated. Migration of mono-, di-, and trinucleosome length DNA is indicated.

\section{Genes encoding yeast CAF-I subunits}

The CAC1 [Chromosome XVI open reading frame (ORF) YPR018w in the Yeast Protein Database] has also been isolated in a screen for genes affecting telomere function (see Discussion; Enomoto et al., this issue). Of the three CAF-I subunits, the yeast $\mathrm{p} 90$ protein is the least similar to its human counterpart, with $\sim 25 \%$ identity (Fig. $3 \mathrm{~B}$ ). Like human $\mathrm{p} 150$, yeast $\mathrm{p} 90$ does contain highly charged lysine/glutamate/arginine-rich (KER) and glutamate/aspartate-rich (ED) regions. However, the proline/gluta- mate/serine/threonine-rich (PEST) region found in human p150 is absent (Fig. 3A,B).

Like the human $\mathrm{p} 60$ protein, the yeast $\mathrm{p} 60$ (Cac2p) subunit contains WD-repeat sequences. However, it lacks the PEST region found at the carboxyl terminus of the human protein. In the WD-repeat region, the human and yeast proteins are $34 \%$ identical; inclusion of conservative changes increases the homology to $47 \%$. More significantly, the alignment of the two proteins shows that the homology extends over the length of the entire WD-repeat region and includes residues other than those 
A
Human CAF-I Subunits

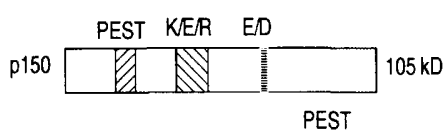

p60 $D D D D E D D^{61 \mathrm{kD}}$

WD40 (GB) repeats

p48 DDDDD 48 kD
Yeast CAF-I Subunits

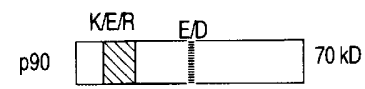

p60 $D D D D D D 53 \mathrm{kD}$

p50
B

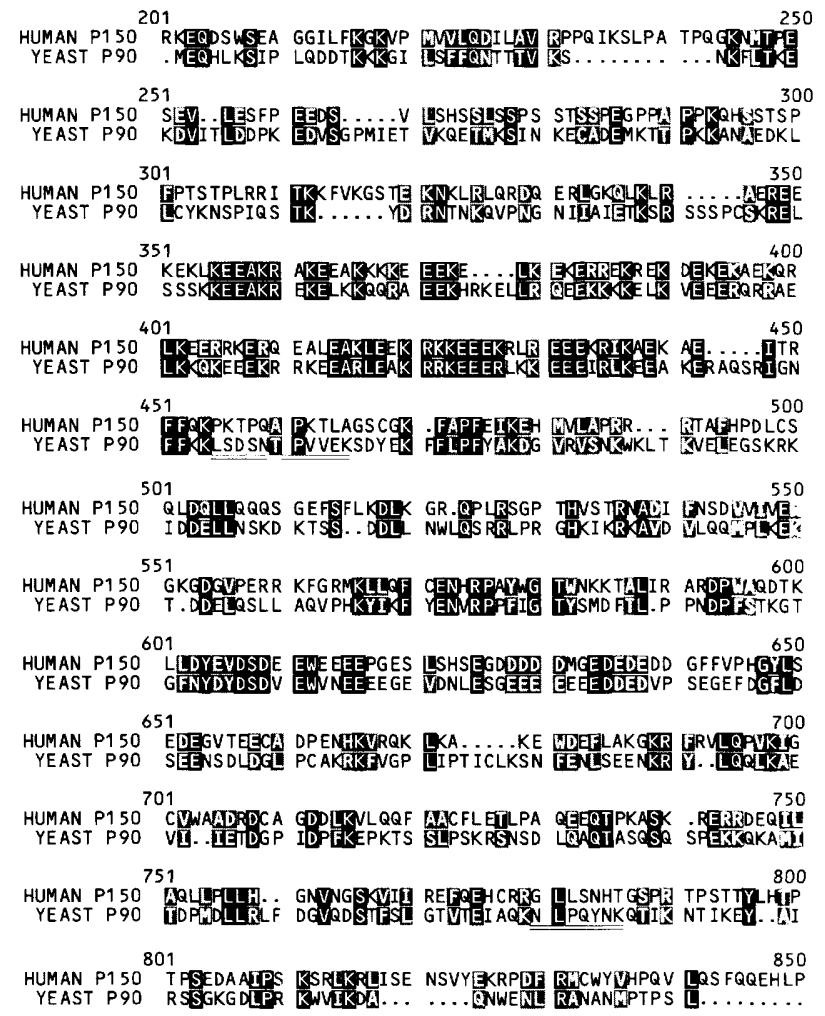

C

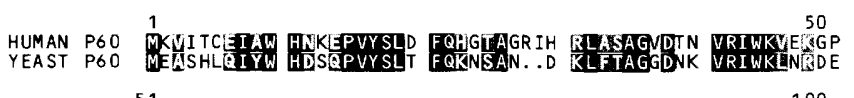

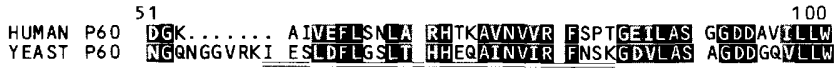
HUMAN P6 101 (150

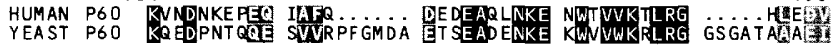
HUMAN P60 00 151 200

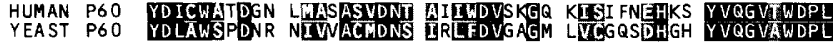
HUMAN P60 201

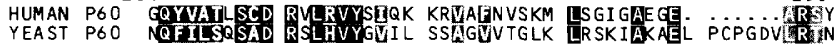

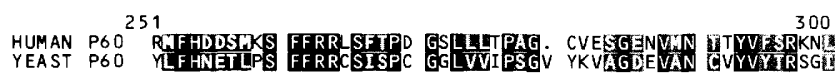
301350

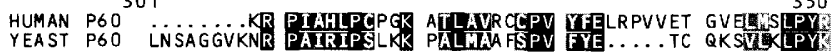

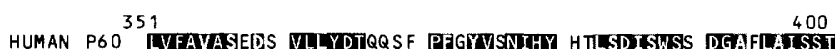

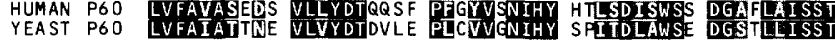
HUMAN P60 401 DGYCSFVTFE IDELGIPLAKE KPVLN... MR TPDTAKKTKS QTHRGSSPGP

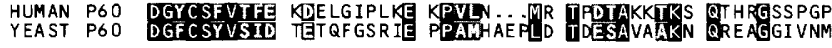
HUMAN P60 451 RPVEGTPASR TQDPSSPGTT PPQARQAPAP TVIRDPPSIT PAVKSPLPGP

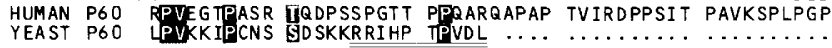
HUMAN P60 501 SEEKTLQPSS QNTKAHPSRR VTLNTLQAWS KTTPRR INLT PLKTDTPPSS

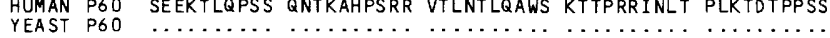
HUMANP60 551 VPTSVISTPS TEEIQSETPG DAQGSPPELK RPRLDENKGG TESLDP

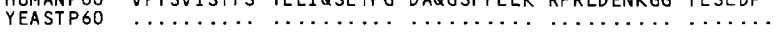

Figure 3. Similarity of yeast CAF-I and human CAF-I subunits. (A) Schematic diagram showing the conserved motifs in the proteins. WD repeats are indicated by triangles. $(B)$ Amino acid sequence alignment of human CAF-I p150 and yeast CAF-I p90 (Caclp). Numbering indicates residues of the human subunit, starting at residue 201; the entire amino acid sequence of Caclp is shown. Alignment was made using the GCG PILEUP program. Identical residues are shaded in black; conserved residues are shaded. Groups of conservative residues are defined as follows: $(\mathrm{L}, \mathrm{A}, \mathrm{V}, \mathrm{I}, \mathrm{F}, \mathrm{M}, \mathrm{Y})$ hydrophobic $;(\mathrm{F}, \mathrm{W}, \mathrm{Y})$ aromatic; $(\mathrm{C}, \mathrm{S}, \mathrm{A}, \mathrm{T}) \mathrm{small} ;(\mathrm{K}, \mathrm{R}, \mathrm{H})$ basic; $(D, E)$ acidic; $(D, N)$ aspartic; and $(E, Q)$ glutamic. Sequenced Caclp peptides are underlined. $(C)$ Amino acid sequence alignment of human CAF-I p60 and yeast CAF-I p60 (Cac2p). Shading is as in $B$. Sequenced Cac2p peptides are double underlined.

that comprise the canonical amino acids that define the repeat itself (Fig. 3C). To date, mutations in the CAC2 gene (chromosome XIII ORF YML102w) encoding yeast p60 have not been described in the literature, nor has the gene been isolated based on genetic interactions with other mutations.

The yeast genome encodes two genes of the p48 protein family (Verreault et al. 1996) that have now been linked to processes involving histones. One gene has been termed histone acetyltransferase subunit 2 (HAT2) (Parthun et al. 1996). This nomenclature reflects the isolation of Hat $2 p$ as a protein that copurified with Hatlp, a B-type histone H4-specific acetyltransferase catalytic subunit (Kleff et al. 1995). The p50 subunit of yeast CAF-I is the other p48 family member, encoded by the MSI1 gene (chromosome II ORF YBR195c). MSI1 was isolated as a multicopy suppressor of growth defects in two different screens (Ruggieri et al. 1989; Hubbard et al. 1992), although it is not clear how this is related to CAF-I function (see Discussion). An alignment of the p48 family members from human and yeast has been published previously (Verreault et al. 1996). Although Hat $2 p$ has greater similarity to human $\mathrm{p} 48$ than Msilp (35\% identical residues for Hat $2 p$ compared to $27 \%$ for 
Msilpl, no peptides derived from Hat $2 p$ were obtained in the amino acid sequence analysis of purified yeast CAF-I.

\section{Ultraviolet radiation sensitivity of cells lacking CAF-I}

Disruption alleles of each of the genes encoding the yeast CAF-I subunits were constructed, and $c a c \Delta$ strains were isolated. These mutants are viable and do not display growth defects under normal growth conditions. However, mutations in yeast histone $\mathrm{H} 4$ can activate a checkpoint that senses DNA damage (Megee et al. 1995), and CAF-I can function during in vitro nucleotide excision repair reactions (Gaillard et al. 1996). Together, these results suggested that proper formation of chromatin may serve to protect the genome from damage. Therefore, we sought to determine whether cacs strains are more sensitive than isogenic wild-type cells to DNAdamaging agents. Indeed, cac $\Delta$ strains display increased sensitivity to ultraviolet (UV) radiation; this phenotype cosegregated with the nutritional marker used to identify the disruption allele in all crosses (Fig. 4A; data not shown). Dosage curves demonstrated that disruption of any of the three $C A C$ genes results in the same degree of UV sensitivity and that there is no additive effect of combining mutations of any or all three genes (Fig. 4B; data not shown). As a control for the efficiency of the radiation treatment, simultaneously we analyzed cells with a deletion of the $R A D 9$ gene, one of the checkpoint genes important for delay of the cell cycle in response to DNA damage (Weinert and Hartwell 1988).

UV radiation results in formation of thymine dimers and other photoproducts that are repaired predominantly by nucleotide excision repair enzymes (for review, see Friedberg and Wood 1996). To determine whether the cac $\Delta$ strains are sensitive to all forms of DNA damage, we also tested sensitivity to gamma-ray irradiation. This treatment produces DNA strand breaks that are repaired in yeast by recombination pathways (Petes et al. 1991; Game 1993). In contrast to their UV sensitivity, cacs strains are no more sensitive to gamma irradiation than wild-type cells (Fig. 4C). In contrast, cells with a deletion of the RAD52 gene, required for repair of damage from ionizing radiation (Game and Mortimer 1974), are markedly sensitive to the given radiation doses.

\section{Defects in telomeric silencing in cac mutants}

$S$. cerevisiae has two types of heterochromatic regions in which gene expression is silenced: silent mating loci and telomere-proximal sequences /Gottschling et al. 1990; Dillin and Rine 1995). Chromatin proteins play a role in this silencing. For example, mutations in the histone $\mathrm{H} 3$ and $\mathrm{H} 4$ amino termini cause derepression of silent loci (Kayne et al. 1988; Johnson et al. 1990; Megee et al. 1990; Park and Szostak 1990). Yeast cells of either a or $\alpha$ mating type that lack CAF-I appear to mate normally (data not shown), indicating that extensive derepression of the normally silent $H M L$ and $H M R$ loci does not occur. Therefore, we tested whether loss of CAF-I would cause derepression of gene expression at telomeric loci.
Derepression of telomere-proximal loci was assayed in strains in which the URA3 gene has been placed next to a telomere (Gottschling et al. 1990; Aparicio et al. 1991; Aparicio and Gottschling 1994). Derepression of URA3 expression is then assayed by quantitating the fraction of cells resistant to 5-fluoro-orotic acid (5-FOA), which kills cells expressing the URA3 gene. A strain with a URA3-marked telomere was crossed into cac1, cac2, and msi1 mutant strains and tested in this assay. As a positive control, a strain with a sir2 null allele displayed the expected complete derepression of telomere-proximal URA3 expression (Table 1; Fig. 5; Aparicio et al. 1991). Significant reduction in the frequency of 5-FOA-resistant cells was also observed in the presence of any of the cac null alleles (Table 1; Fig. 5). At a frequency of $\sim 1$ in $10^{5}$, FOA-resistant colonies of the same size as observed for wild-type strains were observed in the cac mutants. These colonies were fully grown in $2-3$ days at $30^{\circ} \mathrm{C}$. However, the majority of FOA-resistant cac cells were in the form of microcolonies, seen as a faint lawn of cells in the least diluted samples that were best visualized after 5 days of growth (Fig. 5B).

\section{Discussion}

We show that all three subunits of the nucleosome assembly factor CAF-I are conserved between yeast and humans. In both of these organisms, CAF-I subunits form complexes that possess similar biochemical functions. Specifically, CAF-I from both yeast (Fig. 1-3) and human cells (Smith and Stillman 1989; Kaufman et al. 1995) acts in vitro to assemble nucleosomes onto replicated DNA. We also note that Drosophila CAF-I acts in a similar manner (Kamakaka et al. 1996) and that Drosophila CAF-I contains a 48 family member (Tyler et al. 1996). Therefore, CAF-I appears to be conserved functionally and structurally in widely divergent eukaryotic organisms, suggesting an important role in chromosome assembly. Yeast cells lacking the large subunit of CAF-I cannot localize properly the Rap1p protein (Enomoto et al., this issue), a key component of telomeric heterochromatin (Shore 1994). However, cells lacking CAF-I are viable and do not display growth defects under normal conditions, indicating that chromosomes are formed and functional. Furthermore, cac mutants do not display dramatic derepression of the silent mating type loci (data not shown; Enomoto et al. this issue), suggesting that defects resulting from an absence of CAF-I may not be uniform throughout the chromosomes. The striking homology of the CAF-I proteins in distant eukaryotes suggests an important and conserved biological role. The observed phenotypes in yeast could imply that CAF-I acts at specific regions of the chromosomes, notably the telomeres (see below). Alternatively, CAF-I may play an auxiliary role at loci other than at telomeres, or it may be redundant with other proteins for most of its functions in vivo. The isolation of the three $C A C$ genes will allow for genetic and biochemical approaches to identify other proteins involved in chromosome assembly. 


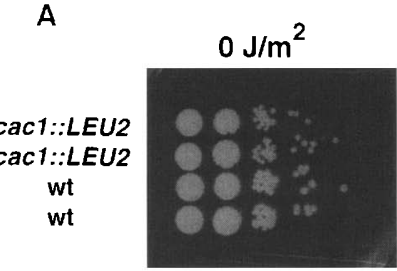

B

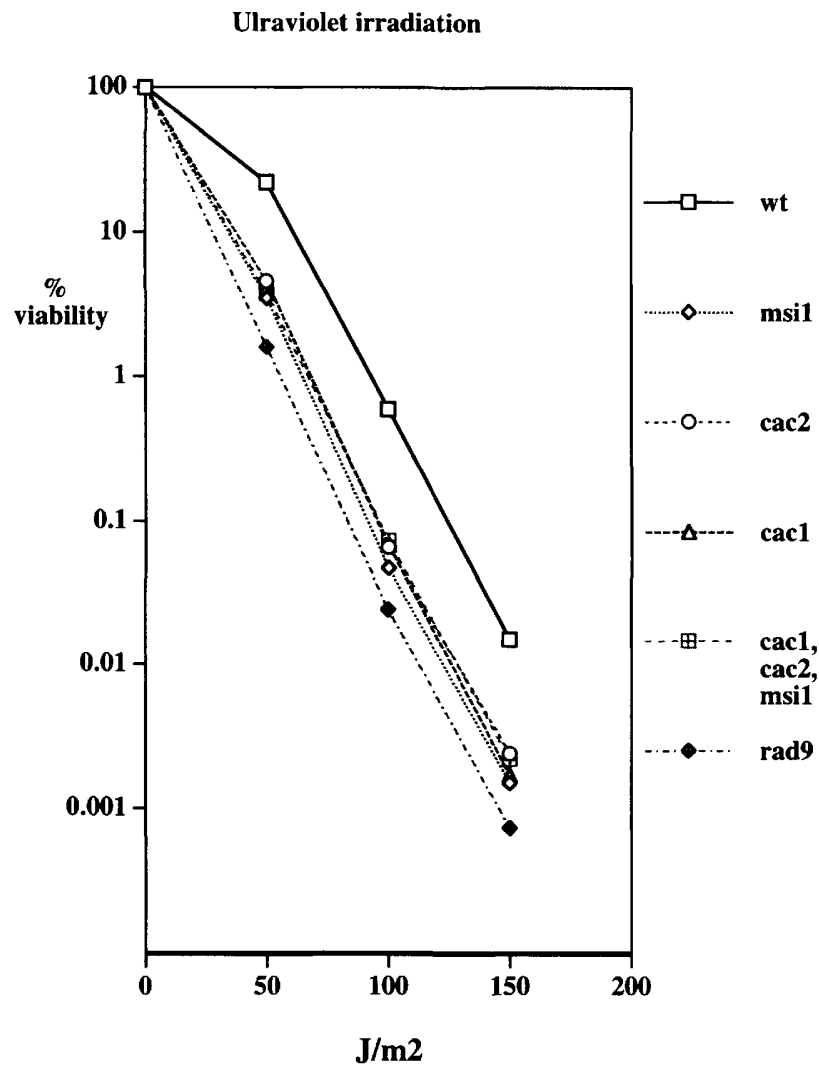

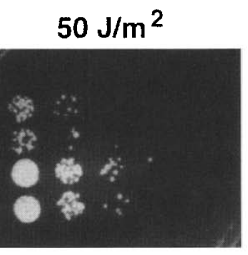

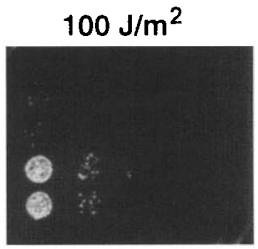

C

Gamma irradiation

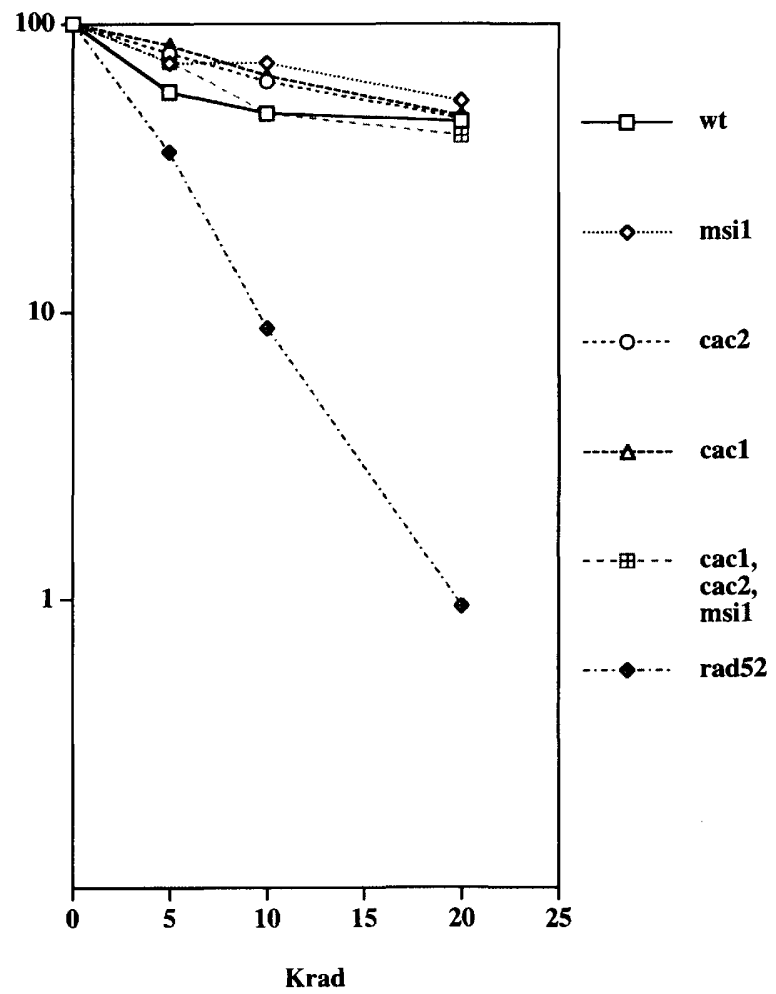

Figure 4. Radiation sensitivity of cacs mutant strains. $(A)$ Comparison of wild-type and cac $\Delta$ mutant cells. Four haploid spores were dissected from diploid yeast strain PKY010 (heterozygous for the cac1::LEU2 allele). Tenfold serial dilutions of log-phase cells were spotted onto a rich medium (YPAD) plate and either not treated (left), exposed to $50 \mathrm{~J} / \mathrm{m}^{2} \mathrm{UV}$ radiation $(\mathrm{middle})$, or $100 \mathrm{~J} / \mathrm{m}{ }^{2} \mathrm{UV}(\mathrm{right})$ before growth for 2 days at $30^{\circ} \mathrm{C}$. The upper two spores are $\mathrm{Leu}^{+}$; the lower two spores are $\mathrm{Leu}^{-} .(B) \mathrm{UV}$ radiation survival curve. Strains PKY028 (MATa; wild-type W303 strain) and isogenic derivatives PKY020 (cac1::LEU2), YB0152 (cac2::TRP1), YB0145 (cac3::URA3), and PKY038 (cac1::LEU2; cac2::TRP1; cac3::URA3) were exposed to the indicated doses of UV light, and viable colonies were counted after growth for 3 days. As a positive control for the efficiency of the irradiation, strain JRY2833 (MATa, his3, leu2-3,112, ura3-52, $\operatorname{trp} 1-289$, rad9::URA3) (not isogenic to W303) was irradiated at the same time. (C) Gamma-radiation survival curve. Strains PKY028 (MATa; wild-type W303 strain) and isogenic derivatives PKY020 (cac1::LEU2), YB0152 (cac2::TRP1), YB0145 (cac3::URA3), and PKY038 (cac1::LEU2; cac2::TRP1; cac3::URA3), were exposed to the indicated doses of gamma radiation, and viable colonies were counted after growth on YPAD for 3 days. As a positive control for the efficiency of the irradiation, strain BL31-2c (W303 derivative, MATa; rad52::TRP1; URA3-ADE2-VILL (Li and Lustig 1996) was irradiated at the same time.

\section{Links between DNA synthesis and CAF-I activity}

In vitro, a transiently formed structure on replicated DNA stimulates nucleosome assembly by CAF-I (Kamakaka et al. 1996; for review, see Kaufman 1996). Although CAF-I was discovered and characterized using bidirectional SV40 DNA replication reactions (Smith and Stillman 1989; Stillman 1986), recent biochemical experiments show that human CAF-I can function during DNA synthesis reactions initiated by nucleotide ex- cision repair of DNA damage (Gaillard et al. 1996). We propose that CAF-I is activated by a signal generated during DNA synthesis, regardless of whether the template is undergoing replicative or repair synthesis.

A prediction of this model is that processes requiring DNA synthesis should be affected in cells lacking CAF-I. The availability of $c a c$ mutants allowed us to test this for the first time. Yeast cells lacking CAF-I display increased sensitivity to UV radiation, but not gamma radiation (Fig. 4). UV causes damage that is chiefly repaired 
Table 1. Silencing of a telomere-proximal URA3 gene in cac strains

\begin{tabular}{lcccr}
\hline Strain & Relevant genotype & $\begin{array}{c}\text { Large FOA-resistant } \\
\text { colonies }(3 \text { days })\end{array}$ & $n$ & $\begin{array}{c}\text { FOA-resistant } \\
\text { microcolonies }(5 \text { days })\end{array}$ \\
\hline PKY090 & wt & $0.55 \pm 0.17$ & 6 & N.A. \\
PKY106 & cac1 & $<(2.1 \pm 1.5) \times 10^{-5}$ & 6 & $0.011 \pm 0.003$ \\
PKY107 & cac2 & $(5.8 \pm 6.5) \times 10^{-5}$ & 6 & $0.012 \pm 0.007$ \\
PKY108 & cac1, cac2 & $(4.2 \pm 1.1) \times 10^{-5}$ & 4 & $0.021 \pm 0.019$ \\
PKY116 & msi1 & $<5.4 \pm 2.1) \times 10^{-5 b}$ & 4 & $0.042 \pm 0.019$ \\
JRY4470 & sir2 & $<1.8 \pm 10^{-7 c}$ & 5 & N.A. \\
\hline
\end{tabular}

The fraction of FOA-resistant cells in a population was determined for these strains as described in Materials and Methods. Colonies of the same size as observed for the wild-type (wt) PKY090 strain were counted after 3 days at $30^{\circ} \mathrm{C}$; microcolonies that arise in the cac strain were counted after 5 days. The mean number of FOA-resistant colonies \pm the standard deviation is shown. (n) The number of independent measurements using different cultures. (N.A.) Not applicable; these strains do not form microcolonies on FOA.

${ }^{a}(<)$ In one experiment, no large FOA-resistant colonies were observed out of $6.2 \times 10^{4}$ plated.

$\mathrm{b}^{\mathrm{b}}<$ In one experiment, no large FOA-resistant colonies were observed out of $4.1 \times 10^{4}$ plated.

$c^{c}<1$ In five experiments, no FOA-resistant colonies were observed out of $5.6 \times 10^{6}$ plated.

by nucleotide excision repair, a mechanism that involves DNA synthesis using many of the same proteins involved in bidirectional DNA replication (Friedberg and Wood 1996). In contrast, gamma radiation causes doublestrand breaks that are thought to be repaired by mechanisms involving recombination (Petes et al. 1991; Game 1993). As observed in vitro (Gaillard et al. 1996), we propose that DNA synthesis performed during nucleotide excision repair activates CAF-I activity in vivo. In cells lacking CAF-I, either nucleotide excision repair itself may be less efficient, or improper reformation of nucleosomes over repaired regions may lead to reduced viability. In contrast, the observed resistance of $c a c$ mutants to gamma rays suggests that recombination during strand break repair does not require CAF-I for chromatin reformation.

Another interpretation of the increased UV sensitivity of cac mutant cells suggests that DNA could be more susceptible to UV damage because of incomplete chromatin assembly. However, this hypothesis fails to explain why there is not increased sensitivity to all damaging agents.

\section{Reduction of telomeric silencing in cac mutants}

CAF-I is required for normal levels of the silencing of a telomere-adjacent gene (Table 1; Figure 5; Enomoto et al., this issue). Within a population of cac mutant cells, there appear to be at least three different epigenetic states at a telomere. First, the majority of cac mutant cells are unable to repress a telomeric URA3 reporter gene sufficiently to allow growth on FOA (Fig. 5). In addition, there are two distinguishable types of FOA-resistant colonies formed by cac strains in these experiments. At a frequency approximately between $10^{-5}$ and $10^{-4}$, these colonies grow as rapidly and attain the same size as observed for a wild-type strain. At much higher frequency $\left(>10^{-2}\right)$, microcolonies are observed, suggesting that the telomeric $U R A 3$ reporter gene may be subject to incomplete or fluctuating silencing in a subset of the population in the absence of CAF-I. These phenotypes are best explained at this point by the fact that the $C A C 1$ gene has also been identified as $R L F 2$ (R्paplp localization factor-2), which is required for normal telomeric localization of the Raplp protein (Enomoto et al., this issue). We also note that growth of FOA-resistant cells in a telomere-marked msi1 mutant strain is qualitatively different; the microcolonies appear larger than observed for the cac1 and cac2 strains (Fig. 5; data not shown). Although presently we do not have a mechanistic explanation for this observation, one possibility is that other $\mathrm{p} 48$ family members can substitute partially for Msilp in vivo, resulting in a less severe deficit in telomeric chromatin structure in msi1 cells. Alternatively, the difference in growth on FOA could result indirectly from a growth advantage unrelated to telomeric chromosome structure (see below).

Therefore, defects in chromosome structure in cells lacking CAF-I have most easily been observed at telomeres. Yeast telomeric DNA acquire single-stranded 3' overhangs even in cells lacking telomerase, the enzyme responsible for synthesis of the telomeric simple-sequence repeats (Wellinger et al. 1996). This result is consistent with proposed mechanisms in which a $5^{\prime} \rightarrow 3^{\prime}$ nuclease acts to expose single-stranded DNA with a free 3 ' end (Lingner et al. 1995). The accumulation of singlestranded DNA at telomeres in cdc13-1 mutants could result from loss of regulation of this putative nuclease (Garvik et al. 1995). Conceivably, there may be multiple rounds of nucleolytic degradation and resynthesis in a dynamic equilibrium process at the telomeres. In turn, this would lead to more frequent utilization of chromatin assembly proteins at telomeres; therefore defects in chromatin assembly would become observed most easily at telomeres. Alternatively, CAF-I may be a specialized chromatin assembly factor responsible mainly for formation of telomeric heterochromatin in yeast.

\section{CAC3 is MSIl}

As observed for human and Drosophila CAF-I, the p50 subunit of yeast CAF-I is encoded by a member of the 
A
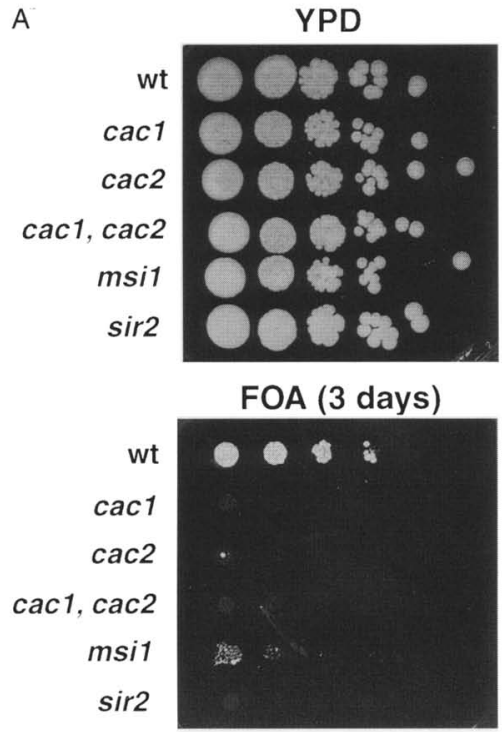

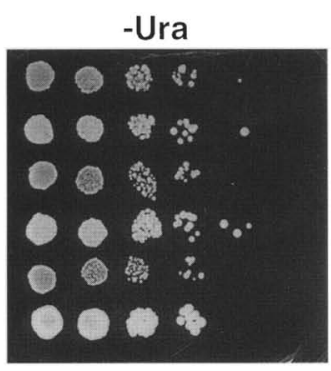

FOA (5 days)

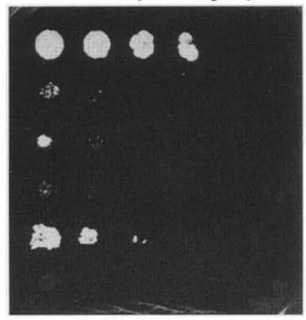

B

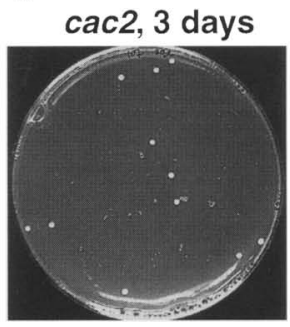

msi1, 3 days

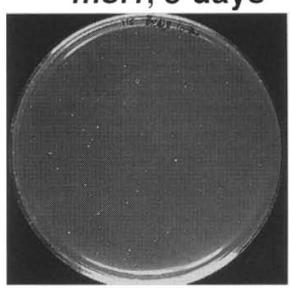

wt, 5 days

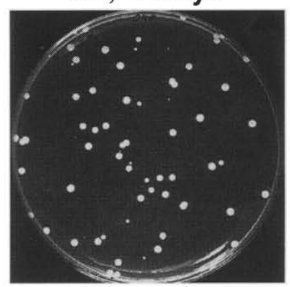

cac2, 5 days

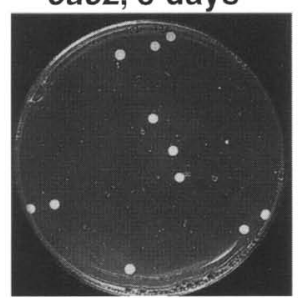

msi1, 5 days

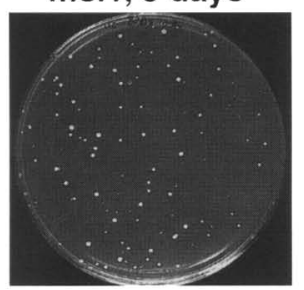

sir2, 5 days

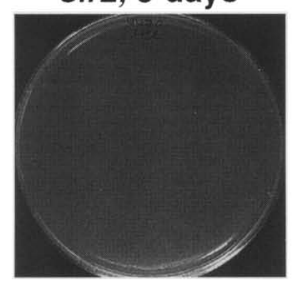

Figure 5. Silencing of a telomeric-proximal URA3 gene in cac mutants. (A) Serial dilution analysis. Strains analyzed were PKY090 (MATa; wild-type W303 strain background containing URA3-VIIL), and isogenic derivatives PKY106 (cac1::LEU2), PKY107 (cac2::TRP1), PKY108 (cac1::LEU2; cac2::TRP1), PKY116 (msi1::hisG), and JRY4470 (sir2::LEU2). Tenfold serial dilutions of log-phase cells were plated onto rich medium to determine total cell density (YPD), medium lacking uracil to select for cells with active URA3 genes (-Ura), or medium containing 5-FOA to select for cells not able to express URA3 (FOA). The FOA plate was photographed after 3 days and 5 days of growth at $30^{\circ} \mathrm{C}$. $\{B\}$ Colony size of FOA-resistant cells. Cells $\left\{6.2 \times 10^{4}\right\}$ of strain PKY107 (cac2, top $\}$ were plated onto an FOA plate and photographed after 3 days (left) and 5 days (right) at $30^{\circ} \mathrm{C}$. Both large and small colony sizes are evident after 5 days. Similar sized colonies were observed for PKY106 and PKY108 (see A, and data not shown). Cells $\left(4.1 \times 10^{3}\right)$ of cells of strain PKY116 (msi1) were analyzed similarly (bottom). For comparison, $1.7 \times 10^{2}$ cells of wild-type strain PKY090 and $7.6 \times 10^{5}$ cells of sir2 strain JRY4470 were plated and photographed after 5 days incubation on FOA media.

p48 subfamily of WD repeat proteins; these proteins have been implicated in histone binding and modification (Parthun et al. 1996; Taunton et al. 1996; Tyler et al. 1996; Verreault et al. 1996). The p50 protein isolated as part of yeast CAF-I is encoded by a gene we termed $C A C 3$, which has been previously called MSI1. The MSI1 gene had been recovered in two different dosagesuppression screens. Overexpression of the MSI1 gene suppresses the heat shock sensitivity of ira1 and activated RAS2 alleles /thus, the name multicopy suppressor of IRA; Ruggieri et al. 1989|. The $\overline{I R A 1}$ gene encodes a GTPase-activating protein that stimulates the intrinsic GTPase activity of Ras proteins (Ruggieri et al. 1989). ira1 mutants or constitutively active RAS2 alleles cause increased intracellular levels of AMP and sensitivity to heat shock. In another screen, Msilp overexpression suppressed the inability of $s n f 4$ strains (a sucrose nonfermenting strain) to grow on nonfermentable carbon sources (Hubbard et al. 1992). In both of these cases, normal expression levels of MSI1 did not suppress the mutant phenotype.
It is presently unclear how MSI1 overexpression suppresses these two distinct phenotypes. One hypothesis is that the role of MSI1 as part of a CAF-I complex is required for proper deposition of nucleosomes at specific cellular promoters; therefore, overexpression of MSI1 might lead to titration of chromatin assembly factors and misregulation of a subset of genes (e.g., genes regulating cAMP levels or those required for growth on nonfermentable carbon sources). Another hypothesis, not mutually exclusive of the first, is that Msilp, like the human p48 subunit (Taunton et al. 1996; Verreault et al. 1996), may exist in a large number of multiprotein complexes, only one of which is CAF-I. In this case, MSII may have a role in processes not directly related to chromatin assembly.

Future experiments are required to determine whether loss or overexpression of MSI1 affects chromatin structure or expression of specific genes and whether proteins other than CAF-I subunits bind to Msilp in vivo. We note, however, that loss of any of the three CAF-I subunits results in quantitatively equivalent sensitivity to 
UV damage (Fig. 4B), suggesting that it is the three-polypeptide CAF-I protein that is required to protect cells from UV damage.

\section{Materials and methods}

\section{Large-scale purification of yeast CAF-I}

Whole cell extracts of protease-deficient $S$. cerevisiae strain BJ926 were prepared as described (Bell et al. 1993). Four hundred grams of cells were used per preparation. All steps were carried out at $4^{\circ} \mathrm{C}$, and $1 \mathrm{mM}$ DTT, $1 \mathrm{mM}$ PMSF, $1 \mathrm{~mm}$ benzamidine, 100 $\mu \mathrm{g} / \mathrm{ml}$ of bacitracin, and $1 \mu \mathrm{g} / \mathrm{ml}$ of pepstatin were added to all buffers. The initial ammonium sulfate pellet was resuspended in $100 \mathrm{ml}$ of buffer A [25 mM Tris-HCl (pH 7.5), 1 mM EDTA, $0.01 \%$ NP-40, $10 \%$ glycerol], and dialyzed versus 4 liters of buffer A plus $0.1 \mathrm{M} \mathrm{NaCl}$ until the conductivity approximated buffer $\mathrm{A}+0.2 \mathrm{M} \mathrm{NaCl}$. The extract was spun at $10,000 \mathrm{rpm}$ for 15 $\mathrm{min}$ in a Sorvall GSA rotor, and the clarified extract $(178 \mathrm{ml}, 7.5$ grams protein) was used for purification. The protein extract (1.9 grams) was loaded onto a 100-ml S-Sepharose column (Pharmacia) equilibrated in buffer $\mathrm{A}+0.2 \mathrm{M} \mathrm{NaCl}$. Unbound proteins were washed away with nine-column volumes of buffer $\mathrm{A}+0.2 \mathrm{M}$ $\mathrm{NaCl}$, and bound proteins were eluted with an $800-\mathrm{ml}$ gradient from buffer $\mathrm{A}+0.2 \mathrm{M}$ to buffer $\mathrm{A}+0.6 \mathrm{NaCl}$.

A $170-\mathrm{ml} \mathrm{S}$-Sepharose fraction centered around buffer $\mathrm{A}+0.27$ $\mathrm{M} \mathrm{NaCl}$ ( $-66 \mathrm{mg}$ of protein) was pooled based on conductivity and loaded onto a $0.7-\mathrm{ml}$ Poros HQ20 column equilibrated in buffer I [ $25 \mathrm{~mm}$ imidazole-HCl (pH 6.7), $1 \mathrm{~mm}$ EDTA, $0.01 \%$ NP-40, $10 \%$ glycerol] $+0.27 \mathrm{M} \mathrm{NaCl}$ using a Pharmacia FPLC system. The Poros HQ column was step-eluted with $5 \mathrm{ml}$ of buffer I+0.4 M NaCl, and remaining bound proteins were eluted with a 10 -ml gradient from buffer I +0.4 to buffer $\mathrm{I}+1.0 \mathrm{M} \mathrm{NaCl}$. Proteins eluting in a broad peak between 0.5 and $0.9 \mathrm{M} \mathrm{NaCl}$ were assayed for CAF-I activity (see below), and active fractions were pooled $(7.5 \mathrm{ml}, 3 \mathrm{mg}$ of protein) and dialyzed versus buffer $\mathrm{H}$ [25 mM HEPES-NaOH (pH 8.0), 1 mM EDTA, 0.01\% NP-40, $10 \%$ glycerol] $+0.1 \mathrm{M} \mathrm{NaCl}$. These proteins were loaded onto a $0.4-\mathrm{ml}$ single-strand DNA cellulose column (U.S. Biochemical) equilibrated in buffer $\mathrm{H}+0.1 \mathrm{M} \mathrm{NaCl}$. Unbound proteins were eluted with $4 \mathrm{ml}$ of buffer $\mathrm{H}+0.1 \mathrm{M} \mathrm{NaCl}$, and the column was then step-eluted with $3 \mathrm{ml}$ of buffer $\mathrm{H}+0.3 \mathrm{M} \mathrm{NaCl}$. Eluted proteins ( $-8.8 \mathrm{mg}$ protein) were loaded onto a $0.3-\mathrm{ml}$ Poros HS column equilibrated in buffer $\mathrm{H}+0.3 \mathrm{M} \mathrm{NaCl}$, washed with $4 \mathrm{ml}$ of buffer $\mathrm{H}+0.3 \mathrm{M} \mathrm{NaCl}$, and eluted by an 8 -ml gradient from 0.3 to $0.7 \mathrm{M} \mathrm{NaCl}$. Proteins eluting as a broad peak were concentrated by chromatography on a $0.1-\mathrm{ml}$ SP-Sepharose column by binding in buffer $\mathrm{H}+0.1 \mathrm{M} \mathrm{NaCl}$ and were eluted with buffer $\mathrm{H}+0.5 \mathrm{M} \mathrm{NaCl}$. Concentrated proteins were separated on a $5-\mathrm{ml}$ $15-35 \%$ glycerol gradient in buffer $\mathrm{A}+25 \mathrm{mM} \mathrm{NaCl}$ spun at $49,000 \mathrm{rpm}$ for $18 \mathrm{hr}$ in a Beckmann SW55 rotor. Thirteen 350$\mathrm{ml}$ fractions were collected manually from the top of the gradient. Three hundred twenty-five microliters each of fractions 5 , 6 , and 7 was brought to $20 \%$ trichloroacetic acid (TCA), $0.08 \%$ sodium deoxycholate (DOC), precipitated, and separated on a preparative SDS- $10 \%$ polyacrylamide gel.

The p90, p60, and p50 bands were detected by Coomassie blue G staining, excised, digested with Achromobacter protease I, and prepared for amino acid sequence analysis as described (Wang et al. 1996). The peptide sequences obtained from p90 and $\mathrm{p} 60$ are shown in Figure $3 \mathrm{~B}$ and $3 \mathrm{C}$, respectively. The peptide sequences obtained from p50 were DITHEASSIPIDLQERYSHWK, LLYDYLNTNSTK, and PAGNLVGHS. These are all encoded by the MSI1 gene (Ruggieri et al. 1989; Verreault et al. 1996).
Histone-agarose chromatography of yeast CAF-I

Active chromatin assembly factor fractions from the singlestrand DNA column were diluted to a conductivity equal to that of buffer $\mathrm{A}+0.1 \mathrm{M} \mathrm{NaCl}$ and loaded onto a $0.15-\mathrm{ml}$ histoneagarose column (Sigma) equilibrated in buffer $\mathrm{A}+0.1 \mathrm{M} \mathrm{NaCl}$. The column was washed with $1 \mathrm{ml}$ of Buffer $\mathrm{A}+0.1 \mathrm{M} \mathrm{NaCl}$ and step eluted with $1 \mathrm{ml}$ each of buffer $\mathrm{A}+0.2 \mathrm{M} \mathrm{NaCl}, 0.4 \mathrm{M} \mathrm{NaCl}$ and $0.6 \mathrm{M} \mathrm{NaCl}$.

\section{SV40 replication assays and product analyses}

Replication reactions were performed and analyzed as described (Kaufman et al. 1995), except that incubation was performed at $30^{\circ} \mathrm{C}$ for $70-80 \mathrm{~min}$. In some cases (e.g., Fig. $1 \mathrm{C}, \mathrm{D}$, lanes $2-4$ ), CAF-I fractions were diluted in buffer A containing $0.1 \mathrm{mg} / \mathrm{ml}$ of acetylated BSA, $1 \mathrm{~mm}$ DTT, before assay. Products were analyzed by gel electrophoresis in $1 \%$ agarose gels.

MNase digestion of replication products was performed as described (Kaufman et al. 1995), with the following modifications: $120 \mu \mathrm{l}$ of DNA replication-coupled chromatin assembly reactions supplemented with $100 \mathrm{ng}$ of histones $\mathrm{H} 2 \mathrm{~A} / \mathrm{H} 2 \mathrm{~B}$ purified from human 293 cells were incubated at $30^{\circ} \mathrm{C}$ for $80 \mathrm{~min}$. $\mathrm{CaCl}_{2}$ was then added to $5 \mathrm{~mm}$ final concentration, and reactions were divided into $25 \mu \mathrm{l}$ aliquots before digestion for the indicated amounts of time with 0.2 units of MNase (Sigma) at $20^{\circ} \mathrm{C}$. Products were analyzed by gel electrophoresis in $2 \%$ agarose gels and autoradiography.

\section{Disruption alleles of the CAC genes}

Yeast strains used in this work are listed in Table 2. In all cases, disruption alleles were constructed by single-step gene replacement in wild-type diploid W303-1 cells (homozygous for leu2-3, 112, ura3-1, his3-11,15, trp1-1, ade2-1, can1-100), and appropriate prototrophic markers were selected using standard genetic techniques (Kaiser et al. 1994). Correct integration was confirmed by Southern blot DNA hybridization. Mutant haploid cells were isolated as prototrophically marked haploids derived from the sporulated diploids.

CAC1 A 5.6-kb BamHI fragment from yeast cosmid 9513 (ATCC) was cloned into the BamHI site of pBSKS+ (Stratagene) to generate plasmid pPK98. The insert is oriented such that the $5^{\prime}$ end of the CAC1 gene is closer to the SacI site of the polylinker. pPK98 was digested with $B g I I I$ and NheI, removing $1.5 \mathrm{~kb}$ of the CAC1 coding sequence, including the ATG start codon. A BamHI-XbaI fragment of pJJ283 (Jones and Prakash 1990 ) containing the $L E U 2$ gene was inserted into this vector to generate pPK103. pPK103 was digested with BamHI before transformation into W303-1 for generation of the heterozygous cac1 $1:$ :LEU2 disruption strain PKY010. PKY010 was sporulated to generate the haploid PKY020.

CAC2 A 6.2-kb XhoI fragment from yeast cosmid 9514 (ATCC) was cloned into the XhoI site of pBSKS+ (Stratagene) to generate plasmid pPK55. The insert is oriented such that the $5^{\prime}$ end of the $C A C 2$ gene is closer to the $K p n I$ site of the polylinker. pPK55 was digested with $S n a \mathrm{BI}$ and $S p h \mathrm{I}$ to remove the first 1.1 $\mathrm{kb}$ of the CAC2 gene, including the ATG start codon. A SmaISphI fragment of pIJ281 (Jones and Prakash 1990) containing the TRP1 gene was inserted into this fragment to generate pPK57. pPK57 was digested with $\mathrm{XhoI}$ before transformation into W303-1 for generation of the heterozygous cac2 $\triangle:$ TRP1 disruption strain YB0150. YB0150 was sporulated to generate YB0152. 
Table 2. S. cerevisiae strains used

\begin{tabular}{|c|c|c|}
\hline Strain & Genotype & Reference \\
\hline W303-1 & $M A T \mathbf{a} / M A T \alpha ;$ wild-type W303 strain & \\
\hline PKY028 & MATa; wild-type W303 strain & \\
\hline PKY010 & $M A T \mathbf{a} / M A T \alpha ; \operatorname{cac} 1:: L E U 2 / C A C 1$ & this work \\
\hline YB0150 & $M A T \mathbf{a} / M A T \alpha ; \operatorname{cac} 2:: T R P 1 / C A C 2$ & this work \\
\hline YB0149 & $M A T \mathbf{a} / M A T \alpha ; m s i 1:: U R A 3 / M S I 1$ & this work \\
\hline PKY018 & $M A T \mathbf{a} / M A T \alpha ;$ msi1 : hisG-URA3-kan ${ }^{\mathrm{R}}-$ hisG/MSI1 & this work \\
\hline PKY020 & MATa; cac1::LEU2 & this work \\
\hline YB0152 & MATa; cac2::TRP1 & this work \\
\hline YB0145 & MATa; msi1::URA3 & this work \\
\hline PKY041 & $M A T \alpha ;$ cac1::LEU2; cac2::TRP1 & this work \\
\hline PKY038 & MATa; cac1::LEU2; cac2:;TRP1; msi1::URA3 & this work \\
\hline PKY034 & MATa; msi1::hisG-URA3-kan ${ }^{R}-h i s G$ & this work \\
\hline PKY079 & MATa; msi1::hisG & this work \\
\hline PKY090 & MATa; URA3-VIIL & this work \\
\hline PKY106 & MATa; URA3-VIIL; cac1::LEU2 & this work \\
\hline PKY107 & MATa; URA3-VIIL; cac2::TRP1 & this work \\
\hline PKY108 & MATa; URA3-VIIL; cac1::LEU2, cac2::TRP1 & this work \\
\hline PKY116 & MATa; URA3-VIIL; msi1::hisG & this work \\
\hline BL31-2c & MATa; rad52::TRP1; URA3-ADE2-VIIL & $\mathrm{Li}$ and Lustig (1996) \\
\hline JRY4470 & MATa; sir2::LEU2; ura3A::LEU2; TRP1-URA3-VIIL & J. Rine (University of California, Berkeley) \\
\hline JRY2833 & MATa; his3; leu2-3,112; ura3-52; trp1-289; rad9::URA3 & J. Rine \\
\hline
\end{tabular}

All strains listed are derived from W303-1, except for JRY2833. W303-1 is homozygous for leu2-3, 112; ura3-1; his3-11,15; trp1-1; ade2-1; can1-100.

CAC3 (MSI1) Plasmid pJH52 carrying the msi1A::URA3 allele (Hubbard et al. 1992) was digested with KpnI and SphI and transformed into wild-type diploid cells to generate the heterozygous disruption strain YB0149. This construct removes the first twothirds of the MSI1 coding region, including the ATG start codon. YB0149 was sporulated to generate YB0145.

The telomeric silencing assays required a null allele not marked with URA3. A $2.5-\mathrm{kb}$ BstBI-SalI fragment from pJH49 containing the MSI1 gene (Hubbard et al. 1992) was first cloned into ClaI-SalI-digested pBSKS+ to generate plasmid pPK96. pPK96 was digested with ClaI, treated with Klenow polymerase to generate a blunt end, and then digested with BgIII. A 5.4-kb $B a m H I-X b a I / K l e n o w$ fragment containing the URA3 gene and a kanamycin-resistance gene flanked by a direct repeat of bacterial hisG DNA was inserted into the prepared pPK96 vector to generate pPK104. A 7.2-kb BamHI-SalI fragment of pPK104 was used to transform diploid W303-1 cells to generate the heterozygous disruption strain PKY018. PKY018 was sporulated to generate PKY034. PKY034 was incubated on an FOA plate to select for loss of $U R A 3$ by recombination (as described; Alani et al. 1987) to generate PKY079.

\section{Radiation sensitivity experiments}

Log-phase cells $\left(A_{600} \sim 0.3-0.5\right)$ were grown in YPD media (Kaiser et al. 1994) supplemented with $50 \mu \mathrm{g} / \mathrm{ml}$ of adenine (YPAD), collected by brief centrifugation, washed with water, and resuspended to the original volume in water. Cells were dispersed by sonication with a Branson microtip for five bursts at $40 \%$ duty on power setting 3 to prevent clumping. For UV experiments, appropriate dilutions of cells were plated on duplicate YPAD plates and irradiated with a GE germicidal lamp calibrated to deliver $4 \mathrm{~J} / \mathrm{m}^{2}$ per sec. For gamma-ray experiments, cells in water were exposed to a Cesium-137 source for the indicated doses and then plated onto duplicate plates. Cells were grown in the dark at $30^{\circ} \mathrm{C}$ for 3 days before counting; the average of the plate counts is shown. Data are shown from a single preparation of cells, but all the results presented were reproducible in multiple experiments. The rad9 strain used in Figure $4 \mathrm{~A}$ is $\sim 10$-fold less UV sensitive than a W303-based rad9 strain isogenic to the cac strains used (data not shown).

\section{Measurement of telomeric silencing}

Yeast strain PKY028 (MATa; wild-type W303 strain) was transformed with a Sall-NotI fragment of pADH4UCA-IV (D. Gottschling, pers. comm.) to create a shortened left arm of chromosome VII with the URA3 gene adjacent to the telomere as described (Gottschling et al. 1990). Correct integration was confirmed in strain PKY090 by DNA hybridization of Ura ${ }^{+}$transformants with sequences from the truncated $A D H 4$ gene (data not shown). PKY090 was crossed to PKY041 (MATa, cac1::LEU2; cac2::TRP1| to generate the other strains tested. Log-phase cells $\left\{A_{600} \sim 0.3-0.6\right\}$ were prepared as described for the radiation sensitivity experiments. Cells were serially diluted in water, and $5-\mu l$ spots were placed on the indicated media and grown at $30^{\circ} \mathrm{C}$ for 2 days. Alternatively, appropriate dilutions of cells were plated onto either YPAD medium to determine total cell number or on FOA medium and grown at $30^{\circ} \mathrm{C}$. Large cells were counted at 3 days, and microcolonies were counted after 5 days.

\section{Acknowledgments}

We thank J. Berman, K. Collins, J. Game, R. Kamakaka, and A. Verreault for review of this manuscript, A. Lustig and J. Rine for yeast strains, D. Gottschling for the URA3-TEL construct, 
and J. Berman for discussion of results before publication. This work was supported by National Institutes of Health grant CA 13106 (B.S.) and by U.S. Department of Energy contract DE-AC03765SF00098 with the University of California. During the initial studies of yeast CAF-I, P.D.K. was a Smith Kline Beecham Fellow of the Life Sciences Research Foundation.

The publication costs of this article were defrayed in part by payment of page charges. This article must therefore be hereby marked "advertisement" in accordance with 18 USC section 1734 solely to indicate this fact.

\section{References}

Alani, E., L. Cao, and N. Kleckner. 1987. A method for gene disruption that allows repeated use of URA3 selection in the construction of multiply disrupted yeast strains. Genetics 116: 541-545.

Aparicio, O.M. and D.E. Gottschling. 1994. Overcoming telomeric silencing: A trans-activator competes to establish gene expression in a cell cycle-dependent way. Genes \& Dev. 8: 1133-1146.

Aparicio, O.M., B.L. Billington, and D.E. Gottschling. 1991. Modifiers of position effect are shared between telomeric and silent mating-type loci in S. cerevisiae. Cell 66: 12791287.

Becker, P.B. and C. Wu. 1992. Cell-free system for assembly of transcriptionally repressed chromatin from Drosophila embryos. Mol. Cell. Biol. 12: 2241-2249.

Bell, S.P., R. Kobayashi, and B. Stillman. 1993. Yeast origin recognition complex functions in transcription silencing and DNA replication. Science 262: 1844-1870.

Diffley, J.F.X. and B. Stillman. 1991. A close relative of the nuclear, chromosomal high-mobility group protein HMGl in yeast mitochondria. Proc. Natl. Acad. Sci. 88: 7864-7868.

Dillin, A. and J. Rine. 1995. On the origin of a silencer. Trends Biochem. Sci. 20: 231-235.

Dingwall, C., S.M. Dilworth, S.J. Black, S.E. Kearsey, L.S. Cox, and R.A. Laskey. 1987. Nucleoplasmin cDNA sequence reveals polyglutamic acid tracts and a cluster of sequences homologous to putative nuclear localization signals. EMBO J. 6: 69-74.

Enomoto, S., P.D. McCune-Zierath, M. Gerami-Nejad, M. Sanders, and J. Berman. 1997. RLF2, a subunit of yeast chromatin assembly factor $I$, is required for telomeric chromatin fucntion in vivo. Genes \& Dev. (this issue).

Friedberg, E.C. and R.D. Wood. 1996. DNA excision repair pathways. In DNA replication in eukaryotic cells led. M.L. DePamphilis), pp. 249-269. Cold Spring Harbor Laboratory Press, Cold Spring Harbor, NY.

Gaillard, P.-H.L., E.M.-D. Martini, P.D. Kaufman, B. Stillman, E. Moustacchi, and G. Almouzni. 1996. Chromatin assembly coupled to DNA repair: A new role for Chromatin Assembly Factor-I. Cell 86: 887-896.

Game, J. 1993. DNA double-strand breaks and the RAD50RAD57 genes in Saccharomyces. Semin. Cancer Biol. 4: $73-$ 83.

Game, J. and R.K. Mortimer. 1974. A genetic study of X-ray sensitive mutants in yeast. Mutat. Res. 24: 281-292

Garvik, B., M. Carson, and L. Hartwell. 1995. Single-stranded DNA arising at telomeres in $c d c 13$ mutants may constitute a specific signal for the RAD9 checkpoint. Mol. Cell. Biol. 15: 6128-6138.

Glikin, G.C., I. Ruberti, and A. Worcel. 1984. Chromatin assembly in Xenopus oocytes: In vitro studies. Cell 37: 33-41.

Gottschling, D.E., O.M. Aparicio, B.L. Billington, and V.A. Za- kian. 1990. Position effect at $S$. cerevisiae telomeres: Reversible repression of PolII transcription. Cell 63: 751-762.

Han, M., M. Chang, U.-J. Kim, and M. Grunstein. 1987. Histone $\mathrm{H} 2 \mathrm{~B}$ repression causes cell-cycle-specific arrest in yeast: Effects on chromosomal segregation, replication, and transcription. Cell 48: 589-597.

Hubbard, E.J., X.L. Yang, and M. Carlson. 1992. Relationship of the cAMP-dependent protein kinase pathway to the SNF1 protein kinase and invertase expression in Saccharomyces cerevisiae. Genetics 130: 71-80.

Ishimi, Y., K. Sugasawa, F. Hanaoka, and A. Kikuchi. 1991. Replication of the simian virus 40 chromosome with purified proteins. I. Biol. Chem. 266: 16141-16148.

Jackson, V. 1990. In vivo studies on the dynamics of histoneDNA interaction: Evidence for nucleosome dissolution during replication and transcription and a low level of dissolution independent of both. Biochemistry 29: 719-731.

Johnson, L.M., P.S. Kayne, E.S. Kahn, and M. Grunstein. 1990. Genetic evidence for an interaction between SIR3 and histone H4 in the repression of the silent mating loci in Saccharomyces cerevisiae. Proc. Nat. Acad. Sci. 87: 6286-6290.

Jones, J.S. and L. Prakash. 1990. Yeast Saccharomyces cerevisiae selectable markers in pUC18 polylinkers. Yeast 6: $363-$ 366.

Kaiser, C., S. Michaelis, and A. Mitchell. 1994. Methods in yeast genetics. Cold Spring Harbor Laboratory Press, Cold Spring Harbor, NY.

Kamakaka, R.T., M. Bulger, and J.T. Kadonaga. 1993. Potentiation of RNA polymerase II transcription by Gal4-VP16 during but not after DNA replication and chromatin assembly. Genes \& Dev. 7: 1779-1795.

Kamakaka, R.T., P.D. Kaufman, B. Stillman, P.G. Mitsis, and J.T. Kadonaga. 1994. Simian virus 40 origin-and T-antigendependent DNA replication with Drosophila factors in vitro. Mol. Cell. Biol. 14: 5114-5122.

Kamakaka, R.T., M. Bulger, P.D. Kaufman, B. Stillman, and J.T. Kadonaga. 1996. Post-replicative chromatin assembly by Drosophila and human Chromatin Assembly Factor-I. Mol. Cell. Biol. 16: 810-817.

Kaufman, P.D. 1996. Nucleosome assembly: The CAF and the HAT. Curr. Opin. Cell Biology 8: 369-373.

Kaufman, P.D. and M.R. Botchan. 1994. Assembly of nucleosomes: Do multiple assembly factors mean multiple mechanisms? Curr. Opin. Genet. Dev. 4: 229-235.

Kaufman, P.D., R. Kobayashi, N. Kessler, and B. Stillman. 1995. The p150 and p60 subunits of chromatin assembly factor 1 : A molecular link between newly synthesized histones and DNA replication. Cell 81: 1105-1114.

Kayne, P.S., U.J. Kim, M. Han, J.R. Mullen, F. Yoshizaki, and M. Grunstein. 1988. Extremely conserved histone H4 N terminus is dispensable for growth but essential for repressing the silent mating loci in yeast. Cell 55: 27-39.

Kim, U.-J., M. Han, P. Kayne, and M. Grunstein. 1988. Effects of histone $\mathrm{H} 4$ depletion on the cell cycle and transcription of $S$. cerevisiae. EMBO I. 7:2211-2219.

Kleff, S., E.D. Andruis, C.W. Anderson, and R. Sternglanz. 1995. Identification of a gene encoding a yeast histone $\mathrm{H} 4$ acetyltransferase. J. Biol. Chem. 270: 24674-24677.

Kleinschmidt, J.A., C. Dingwall, G. Maier, and W.W. Franke. 1986. Molecular characterization of a karyophilic, histone binding protein: cDNA cloning, amino acid sequence and expression of nuclear protein N1/N2 of Xenopus laevis. EMBO I. 5: 3547-3552.

Krude, T. 1995a. Chromatin assembly factor 1 (CAF-1) colocalizes with replication foci in HeLa cell nuclei. Exp. Cell Res. 220: 304-311. 
1995b. Nucleosome assembly during DNA replication. Curr. Biol. 5: 1232 .

Laskey, R.A., A.D. Mills, and N.R. Morris. 1977. Assembly of SV40 chromatin in a cell-free system from Xenopus eggs. Cell 10: 237-243.

Li, B. and A.J. Lustig. 1996. A novel mechanism for telomere size control in Saccharomyces cerevisiae. Genes \& Dev. 10: $1310-1326$.

Lingner, J., J.P. Cooper, and T.R. Cech. 1995. Telomerase and DNA end replication: No longer a lagging strand problem? Science 269: 1533-1534.

Megee, P.C., B.A. Morgan, B. A. Mittman, and M.M. Smith. 1990. Genetic analysis of histone H4: Essential role of lysines subject to reversible acetylation. Science 247: 841-845.

Megee, P.C., B.A. Morgan, and M.M. Smith. 1995. Histone H4 and the maintenance of genome integrity. Genes \& Dev. 9: 1716-27.

Neer, E.J., C.J. Schmidt, R. Nambudripad, and T.F. Smith. 1994. The ancient regulatory-protein family of WD-repeat proteins. Nature 371: 297-300.

Park, E. and J.W. Szostak. 1990. Point mutations in the yeast histone $\mathrm{H} 4$ gene prevent silencing of the silent mating type locus HML. Mol. Cell. Biol. 10: 4932-4934.

Parthun, M., J. Widom, and D.E. Gottschling. 1996. The major cytoplasmic histone acetyltransferase in yeast: Links to chromatin replication and histone metabolism. Cell 87: 8594.

Petes, T.D., R.E. Malone, and L.S. Symington. 1991. Recombination in yeast. In The molecular and cellular biology of the yeast Saccharomyces: Genome dynamics, protein synthesis and energetics (ed. J.R. Broach, E.W. Jones, and J.R. Pringle), pp. 407-521. Cold Spring Harbor Laboratory Press, Cold Spring Harbor, NY.

Ruggieri, R., K. Tanaka, M. Nakafuku, Y. Kaziro, A. Toh-e, and K. Matsumoto. 1989. MSI1, a negative regulator of the RAScAMP pathway in Saccharomyces cerevisiae. Proc. Natl. Acad. Sci. 86: 8778-8782.

Russev, G. and R. Hancock. 1982. Assembly of new histones into nucleosomes and their distribution in replicating chromatin. Proc. Natl. Acad. Sci. 79: 3143-3147.

Shore, D. 1994. RAP1: A protean regulator in yeast. Trends Genet. 10: 408-412.

Smith, S. and B. Stillman. 1989. Purification and characterization of CAF-I, a human cell factor required for chromatin assembly during DNA replication. Cell 58: 15-25.

- 1991 . Stepwise assembly of chromatin during DNA replication in vitro. EMBO I. 10: 971-980.

Sogo, J.M., H. Stahl, T. Koller, and R. Knippers. 1986. Structure of replicating simian virus 40 minchromosomes. The replication fork, core histone segregation and terminal structures. J. Mol. Biol. 189: 189-204.

Stillman, B. 1986. Chromatin assembly during SV40 DNA replication in vitro. Cell 45: 555-565.

Taunton, J., C.A. Hassig, and S.L. Schreiber. 1996. A mammalian histone deacetylase related to the yeast transcriptional regulator Rpd3p. Science 272: 408-411.

Tyler, J.K., M. Bulger, R.T. Kamakaka, R. Kobayashi, and J.T. Kadonaga. 1996. The p55 subunit of Drosophila Chromatin Assembly Factor-I is homologous to a histone deacetylaseassociated protein. Mol. Cell. Biol. 16: 6149-6159.

van Holde, K.E. 1989. Chromatin (ed. A. Rich). Springer-Verlag, Berlin, Germany.

Verreault, A., P.D. Kaufman, R. Kobayashi, and B. Stillman. 1996. Nucleosome assembly by a complex of CAF-I and acetylated histones H3/H4. Cell 87: 95-104.

Wang, R., R. Kobayashi, and J.M. Bishop. 1996. Cellular adher- ence elicits ligand-independent activation of the Met cellsurface receptor. Proc. Natl. Acad. Sci. 93: 8425-8430.

Weinert, T.A. and L.H. Hartwell. 1988. The RAD9 gene controls the cell cycle response to DNA damage in Saccharomyces cerevisiae. Science 241: 317-322.

Wellinger, R.J., K. Ethier, P. Labreque, and V.A. Zakian. 1996. Evidence for a new step in telomere maintenance. Cell 85: 423-433.

Worcel, A., S. Han, and M.L. Wong. 1978. Assembly of newly replicated chromatin. Cell 15: 969-977.

Wu, R.S. and W.M. Bonner. 1981. Separation of basal histone synthesis from S-phase histone synthesis in dividing cells. Cell 27: 321-330. 


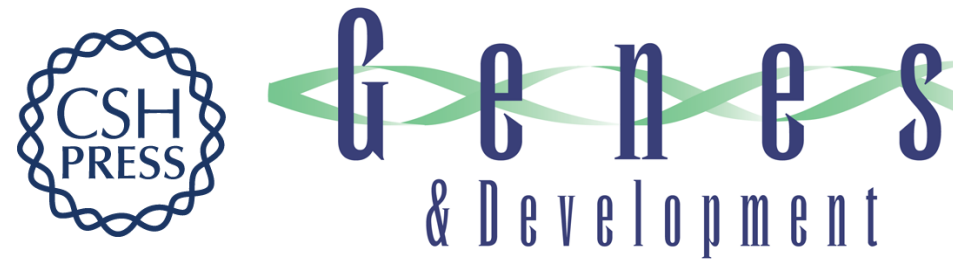

\section{Ultraviolet radiation sensitivity and reduction of telomeric silencing in Saccharomyces cerevisiae cells lacking chromatin assembly factor-l.}

P D Kaufman, R Kobayashi and B Stillman

Genes Dev. 1997, 11:

Access the most recent version at doi:10.1101/gad.11.3.345

References This article cites 55 articles, 24 of which can be accessed free at: http://genesdev.cshlp.org/content/11/3/345.full.html\#ref-list-1

License

Email Alerting Service

Receive free email alerts when new articles cite this article - sign up in the box at the top right corner of the article or click here.

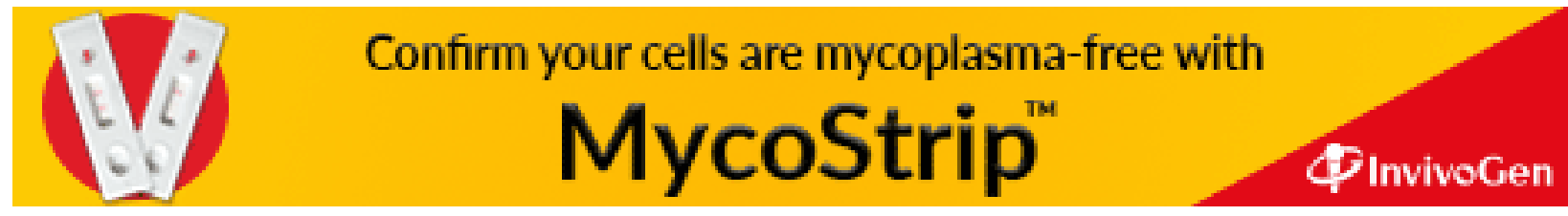

